\title{
Assessing the sensitivity of leeches as indicators of water quality
}

\author{
Agustina Cortelezzi a,*, Bettina S. Gullo ${ }^{\text {b }}$, María V. Simoy ${ }^{a}$, Rosana E. Cepeda ${ }^{\text {a }}$, \\ Claudia B. Marinelli ${ }^{\text {a }}$, Alberto Rodrigues Capítulo ${ }^{\mathrm{c}}$, Igor Berkunsky ${ }^{\mathrm{a}}$
}

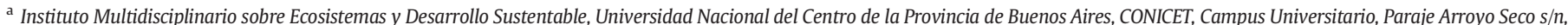
Tandil (7000) Buenos Aires, Argentina

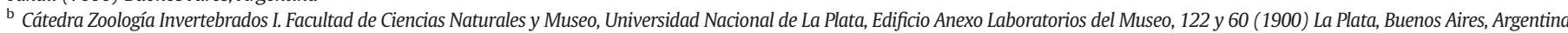

c Instituto de Limnología Dr. Raúl A. Ringuelet, CONICET, CC 712 La Plata (1900), Buenos Aires, Argentina

\section{H I G H L I G H T S}

- At species level, leeches were good indicators of water quality of streams.

- Occupancy modelling offers a new methodology to understand how the species behave along a stressor gradient.

- The species sensitivity description in terms of occupation, will allow researchers to generate more accurate biotic indices.

\section{G R A P H I C A L A B S T R A C T}

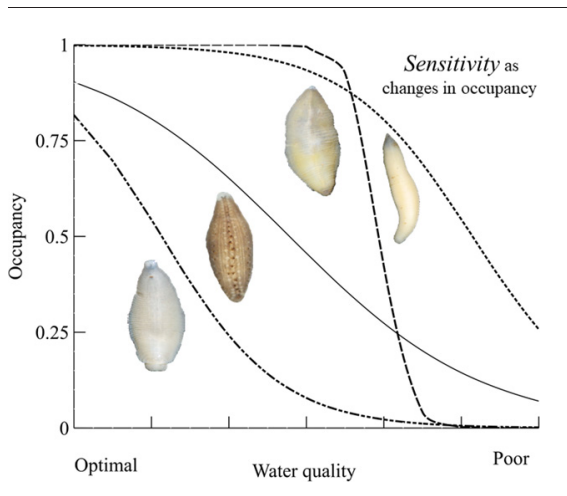

\begin{abstract}
A B S T R A C T
The objective of this work was assessing the sensitivity of leeches to several water quality attributes in lowlands streams. We used occupancy modelling that account explicitly for detectability, to estimate the influence of four variables (dissolved oxygen, 5-days biochemicals oxygen demand, conductivity, and dissolved inorganic nitrogen) affecting nine species. We described the sensitivity as a change in the occupancy along the range of water quality attributes. We found at least one species of Helobdella in $81 \%$ of sites and Helobdella, as genus, was detected along the entire gradient of each attribute. However, differences in the sensitivity were observed between species. For example, if we analyse the sensitivity of the genus Helobdella to dissolved oxygen, we can say that it is very tolerant. However, if we analyse the response to dissolved oxygen of each one of the species of Helobdella, we will realize that $H$. michaelseni, and H. simplex showed a high occupancy at high levels of dissolved oxygen; while $H$. hyalina and $H$. triserialis lineata showed high occupancy at low levels. Describe the sensitivity of the species in terms of occupancy, offers a new methodology to understand how the species behave along a stressor gradient.
\end{abstract}

(c) 2017 Elsevier B.V. All rights reserved.

\section{Introduction}

Hirudinea species are a fundamental component of benthic fauna (Rosenberg and Resh, 1993). Leeches play different roles in the food

\footnotetext{
* Corresponding author.

E-mail address: acorte@exa.unicen.edu.ar (A. Cortelezzi).
}

chain, acting as predators, preys, and even, as intermediate host of Digenea, Cestoda, and Protozoa (Sawyer, 1986). The knowledge of leeches is particularly concentrated in description and redescription of species, construction of phylogenies, and global diversity (Gullo, 2006 2009, 2014; Mosser et al., 2013; Oceguera-Figueroa et al., 2010; Oceguera-Figueroa, 2014; Siddall, 2001; Siddall and Borda, 2004; Siddall et al., 2005; Sket and Trontelj, 2008). The taxonomic identification of 
leeches' species is a complex task, usually requiring specialists, which are very uncommon worldwide. For this reason, in ecological studies leeches are usually included just as Hirudinea or even excluded from the list of indicator organisms (Maxted et al., 2000; Royer et al., 2001).

Several factors may affect the occurrence of leeches. Most of the common leeches species are classified as inhabitants of eutrophic, polysaprobic, moderately and highly stressed freshwater environments (Lenat, 1993). For this reason, leeches are usually included (as a single group) as moderately tolerant or tolerant to organic enrichment and pollution, in the different procedures used in the biological assessment of freshwaters (e.g. Chyla, 1998; Skriver et al., 2000; Pizzolón and Miserendino, 2001). However, information about leeches' relationships with habitat and water quality have been published scarcely (Kubová and Schenková, 2014; Kazancı et al., 2014; Miserendino and Gullo, 2014).

In the Neotropical region, Helobdella Blanchard, 1896 show a high grade of endemic species (Ringuelet, 1985; Christoffersen, 2009), and is one of most abundant and frequent taxa inhabiting lotic and lentic systems of southern cone of South America (Gullo, 2009; Sket and Trontelj, 2008; Christoffersen, 2009). As occurs with most leeches, the knowledge about the ecology of Helobdella species is limited, which makes it hard to assign them sensitivity values based on documented knowledge. The few available sensitivity information for some species are based on either expert knowledge and/or empirical derivation about presence of species in relation to ecosystem attributes (Pearson and Rosenberg, 1978; Rosenberg et al., 2004; Leonardsson et al., 2009).

Occupancy modelling, that account explicitly for detectability, has become increasingly useful to ecologists because provides a flexible framework to investigate ecological questions and processes such as species distribution modelling, habitat relationships, multispecies relationships and community dynamics (Bailey et al., 2014; Berkunsky et al., 2015; Cortelezzi et al., 2017). Recently, occupancy modelling was used to describe the sensitivity of some benthic oligochaete species, offering a new methodology to understand how the occupancy of a species behaves along a stressor gradient (Cortelezzi et al., 2017). Theory predicts the occupancy will decrease as the habitat quality decrease; then, if we are able to identify the stressors affecting species occupancy, we will be able to describe the sensitivity as a change in the occupancy along the range of ecosystem attributes (Boyce et al., 2016; Cortelezzi et al., 2017). The objective of this work was assessing the sensitivity of leeches to several attributes in lowlands streams. We modelled occupancy of species from four physical and chemical attributes of water quality (i.e. dissolved oxygen, BOD5, conductivity, and dissolved inorganic nitrogen); and we described the change in occupancy along the gradient of each explanatory physical and chemical variable.

\section{Materials and methodology}

\subsection{Study area}

The study area is located in the South-eastern of Buenos Aires province, in the area occupied by the Tandilia mountain system. On northern hillside of Tandilia have their headwaters a lot of streams that it drains in direction NE through foothill and plains areas, both with a strong agricultural development. Although this area is considered endangered and of maximum priority due to its great transformation, biological uniqueness, and the absence of protected areas (Bilenca and Miñarro, 2004), currently there is a lack of information on the ecological status of these aquatic systems.

\subsection{Surveys}

We conducted surveys in autumn 2012 and 2015 covering 43 sites distributing in 8 streams. We collected three samples of sediment with an Ekman grab $\left(100 \mathrm{~cm}^{2}\right)$. Samples were fixed in situ with $4 \%$ formaldehyde, and sorted in the laboratory under at least $5 \times$ magnification. Examination of external morphology and posterior dissection of specimens was accomplished with a Leica Wild M3Z stereomicroscope. Species were identified using regional keys (Ringuelet, 1985; Sawyer, 1986) and counted.

At each site, we also collected one sample of water, and we recorded: dissolved oxygen (YSI 52 dissolved oxygen meter), temperature and $\mathrm{pH}$ (Hanna HI 8633), and conductivity (Lutron CD-4303). For each sample of water, we analysed the concentration of phosphate $\left(\mathrm{P}_{-} \mathrm{PO}_{4}^{-3}\right)$, ammonium $\left(\mathrm{N}-\mathrm{NH}^{+4}\right)$, nitrate $\left(\mathrm{N}-\mathrm{NO}_{3}^{-1}\right)$, nitrite $\left(\mathrm{N}-\mathrm{NO}_{2}^{-1}\right)$ and the oxygen demand (BOD 5 and COD; Mackereth et al., 1978; APHA, 1998).

\subsection{Modelling}

We used occupancy models to estimate the influence of physical and chemical variables affecting the occupancy of each leech species. The basis of occupancy model is that there are two stochastic processes occurring that affect whether a species is detected at a site. A site may be either occupied or unoccupied by the species; if it is occupied then at each visit there is some probability of detecting the species. For each site we built a detection history of three simultaneous visits. We evaluated the baseline model for each species, in which both detection and occupancy probabilities were assumed to be constant across all sites [denoted as $\psi() p.($ (.)]. Then, we developed a model set that incorporated site covariates through a logit link function. We explored the structure of covariation of physical and chemical variables, and then we reduced the variables dimension resulting in four independent covariates globally used to define the water quality: dissolved oxygen (\%DO, range from 14 to 160 ), conductivity (range: $185-1207 \mu \mathrm{S} / \mathrm{cm}$ ), dissolved inorganic nitrogen (DIN $=$ ammonium + nitrate + nitrite, range: 0.3-13.1 mgN/l), and five-day biochemical oxygen demand $\left(\mathrm{BOD}_{5}\right.$, range: $0.00-47 \mathrm{mgO} / \mathrm{l})$. Under the assumption that the occupancy of species decrease as the water quality decrease, we expected a negative relationship between occupancy and conductivity, DIN and BOD B $_{5}$ and a positive relationship between occupancy and \%DO. We evaluated all potential models with 2-4 parameters (including the intercept and probability of detection) to avoid the occurrence of spurious results, and by maintaining an approximate ratio of data to parameters $>10(n=43$ sites; maximum number of parameters $=\mathrm{n} / 10$; Burnham and Anderson, 2002). For each model, we calculated the estimates of parameters $(\beta)$ and their standard errors. Also, we excluded those models which all covariates had confidence interval containing the zero. Finally, we ranked models using Akaike's Information Criterion (AIC). We kept all models that were better than constant-occupancy model [i.e., $\psi($. $\mathrm{p}()$.$] and that were less than two AIC units [\triangle \mathrm{AIC}<2$ ] of the best model. For each species, we used the best model to evaluate its sensitivity to physical and chemical covariates. We run the occupancy models with the Unmarked package in R (Fiske and Chandler, 2011).

\subsection{Analysis of sensitivity}

We illustrated the species' sensitivity by describing the three phases of occupancy decline: resistance, tolerance, and extinction (Cortelezzi et al., 2017). The resistance reflects the capacity of species to hold occupancy as habitat quality decreases. In the framework of occupancy modelling, the resistance phase is associated to the intercept of the model (i.e. species with a high resistance will show a higher intercept values) and it can be interpreted according to units of the quality habitat variable. The tolerance phase is the range of the habitat quality variable for which the occupancy shows the highest decline. The extinction phase is defined from the limit value of the habitat quality variable which the occupancy is very low $(<10 \%)$. The joint analysis of the three phases allows describe and compare the sensitivity of species in terms of occupancy. We used VeusZ ${ }^{\circledR}$ to create graphs. 


\section{Results}

We found at least one species of leeches in $81 \%$ of sites. We detected nine species of Helobdella with an average of $2.3 \pm 0.3$ species per site, and a maximum of seven species in a single site. We detected Helobdella, as genus, along the entire gradient of each four physical or chemical variables (Fig. 1).

We modelled the occupancy of the nine species of Helobdella. For six species (H. adiastola, H. hyalina, H. michaelseni, H. simplex, H. triserialis lineata, and $H$. obscura), occupancy was explained by at least one physical or chemical variable; resulting in models that ranked better than the constant model $[\psi() p.()$.$] ; Table 1)$. Occupancy was explained by conductivity and dissolved oxygen in four species, and DIN and $\mathrm{BOD}_{5}$ in other four species. All species of Helobdella included more than one physical or chemical covariate in their models (Table 1 ). For the remaining three species (Helobdella triserialis triserialis, $H$. cordobensis and $H$. brasiliensis) the addition of physical and/or chemical covariates did not improve the constant model.

We describe the occupancy of the six species across the range of each physical and chemical covariate (Fig. 2). H. michaelseni and H. simplex showed a very long tolerance phase for $\% \mathrm{DO}$ and $\mathrm{BOD}_{5}$; and did not show marked extinction phases (Fig. 2a, b). In the case of conductivity, the resistance phase of $H$. michaelseni was higher than the tolerant phase, and the extinction phase was absent (Fig. 2c). H. obscura showed a pronounced tolerance phase, reaching the extinction phase under 20 as \%DO (Fig. 2a). H. triserialis lineata and H. adiastola showed similar behaviour, exhibiting an extended tolerance phase along the conductivity gradient.

Three species (i.e. H. hyalina, H. obscura, and H. triserialis lineata) showed an anti-hypothesis behaviour. Contrary to the expected, these species increased their occupancy in sites with low values of dissolved oxygen or high values of Dissolved Inorganic Nitrogen (Fig. 2a and d).

\section{Discussion}

As expected, Helobdella, as genus, was detected in almost all sites, in all streams, and along the entire gradient of each four physical or chemical variables. Without information about the identity of the species, our observations would match with a vision of Helobdella as an eurioic taxon, ranging from relatively healthy to highly stressed freshwater environments. However, when the identity of the species was included, a simple descriptive analysis of detections suggested differences in the tolerance range of the species.

More than half of modelled leech's species of Pampean streams included at least one physical or chemical covariate in their top models; and we obtained sensitive species (i.e. species which showed a change in their occupancy along the range of the covariate) for the four selected covariates. Six species would have the potential to be assessed as indicator species of habitat quality of streams in this region.

Most of these sensitive leeches responded by varying their occupancy to changes in dissolved oxygen. Despite leeches were found along the whole gradient of dissolved oxygen, a species replacement seems occurring between some species. While H. michaelseni and H. simplex showed a high occupancy at high levels of dissolved oxygen; $H$ hyalina and $H$. triserialis lineata were almost absent in those levels. As far as the dissolved oxygen was reducing the occupancy of $H$. michaelseni and $\mathrm{H}$. simplex decreased, and the occupancy of $H$ hyalina and $H$. triserialis lineata increased. Further studies will be necessary to explore a competition hypothesis between these species of Helobdella. a)

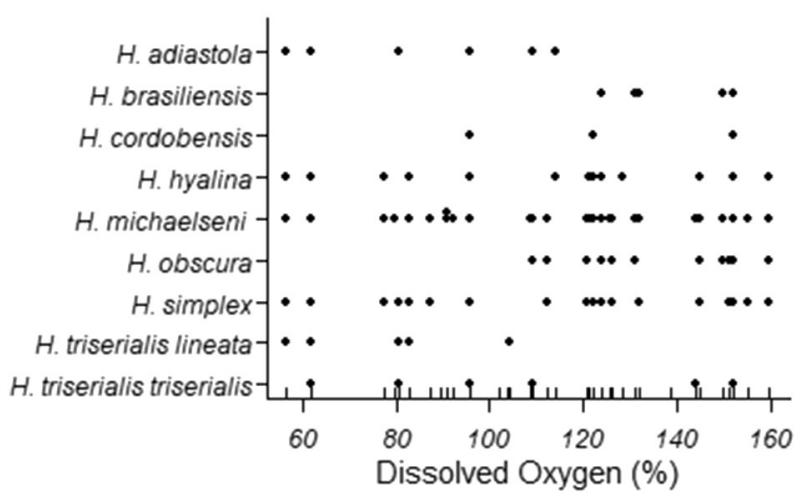

c)

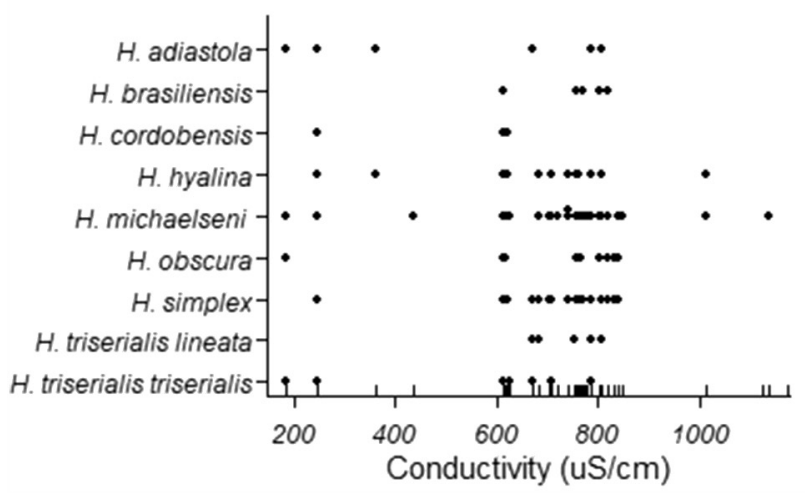

b)

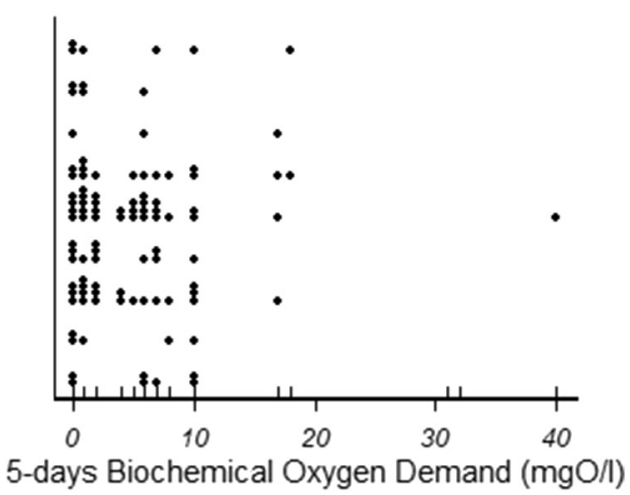

d)

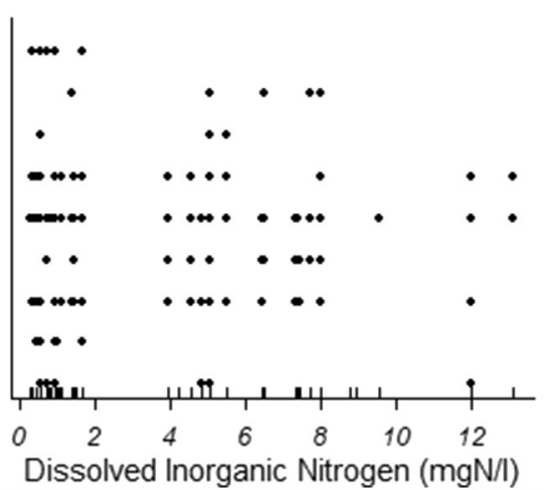

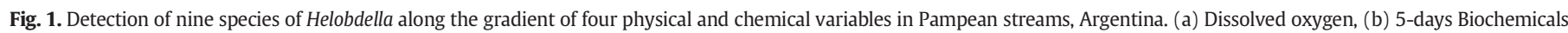
Oxygen Demand, (c) Conductivity, and (d) Dissolved Inorganic Nitrogen. 
Table 1

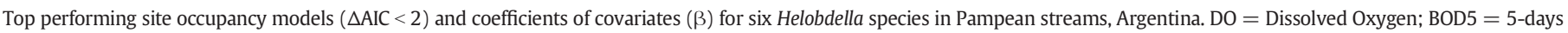
Biochemical Oxygen Demand; DIN = Dissolved Inorganic Nitrogen.

\begin{tabular}{|c|c|c|c|c|c|c|c|c|c|}
\hline Species & Model & $N$ & $\Delta \mathrm{AIC}$ & $p$ & Intercept & Dissolved Oxygen & BOD5 & Conductivity & DIN \\
\hline \multirow[t]{4}{*}{ Helobdella adiastola } & $\Psi$ (Conductivity + DIN) p (.) & 4 & 0.00 & \multirow[t]{4}{*}{0.50} & $-3.54 \pm 1.56$ & & \multirow{4}{*}{$-0.17 \pm 1.30$} & $-1.37 \pm 0.77$ & \multirow[t]{4}{*}{$-2.34 \pm 1.90$} \\
\hline & $\Psi$ (Conductivity) $\mathrm{p}()$. & 3 & 1.43 & & $-2.33 \pm 0.67$ & & & $-1.65 \pm 0.68$ & \\
\hline & $\Psi$ (BOD5 + Conductivity) p (.) & 4 & 3.41 & & $-2.38 \pm 0.78$ & & & $-1.68 \pm 0.74$ & \\
\hline & $\Psi(.) \mathrm{p}()$. & 2 & 9.01 & & $-1.63 \pm 0.48$ & & & & \\
\hline \multirow[t]{8}{*}{ Helobdella hyalina } & $\Psi(\mathrm{DO}+$ Conductivity + DIN $) \mathrm{p}()$. & 5 & 0.00 & \multirow[t]{3}{*}{0.30} & $0.70 \pm 0.87$ & $-2.56 \pm 1.46$ & \multirow{3}{*}{$-0.55 \pm 1.11$} & \multirow{4}{*}{$\begin{array}{l}-5.89 \pm 2.77 \\
-5.64 \pm 2.64\end{array}$} & \multirow{4}{*}{$\begin{array}{l}2.72 \pm 1.40 \\
2.77 \pm 1.35\end{array}$} \\
\hline & $\Psi(\mathrm{DO}+\mathrm{BOD} 5+$ Conductivity + DIN $) \mathrm{p}()$. & 6 & 1.72 & & $0.51 \pm 0.87$ & $-2.60 \pm 1.41$ & & & \\
\hline & $\Psi(.) \mathrm{p}()$. & 2 & 6.28 & & $0.02 \pm 0.65$ & & & & \\
\hline & $\Psi(\mathrm{DO}) \mathrm{p}()$. & 3 & 0.00 & \multirow{5}{*}{0.54} & $1.56 \pm 0.78$ & $1.15 \pm 0.65$ & & & \\
\hline & $\Psi$ (Conductivity) $\mathrm{p}()$. & 3 & 0.28 & & $1.63 \pm 0.75$ & & & \multirow{4}{*}{$-1.28 \pm 0.68$} & \\
\hline & $\Psi($ BOD5) $\mathrm{p}()$. & 3 & 0.46 & & $1.42 \pm 0.65$ & & $-0.94 \pm 0.48$ & & \\
\hline & $\Psi(\mathrm{DO}+\mathrm{DIN}) \mathrm{p}()$. & 4 & 1.23 & & $1.64 \pm 0.79$ & $1.31 \pm 0.74$ & & & $0.42 \pm 0.51$ \\
\hline & $\Psi(.) \mathrm{p}()$. & 2 & 3.45 & & $1.22 \pm 0.48$ & & & & \\
\hline \multirow[t]{2}{*}{ Helobdella obscura } & $\Psi($ BOD5 + DIN) p (.) & 4 & 0.00 & \multirow[t]{2}{*}{0.30} & $-0.31 \pm 0.81$ & & \multirow{2}{*}{$-2.32 \pm 1.26$} & & \multirow{2}{*}{$-3.05 \pm 1.58$} \\
\hline & $\Psi(.) \mathrm{p}()$. & 3 & 8.65 & & $-0.43 \pm 0.60$ & & & & \\
\hline \multirow[t]{4}{*}{ Helobdella simplex } & $\Psi($ BOD5) $\mathrm{p}()$. & 3 & 0.00 & \multirow[t]{4}{*}{0.51} & $0.05 \pm 0.40$ & & \multirow[t]{2}{*}{$-0.86 \pm 0.51$} & & \\
\hline & $\Psi(\mathrm{DO}) \mathrm{p}()$. & 3 & 1.01 & & $0.09 \pm 0.39$ & $0.64 \pm 0.39$ & & & \\
\hline & $\Psi($ BOD5 + DIN) p (.) & 4 & 1.40 & & $0.08 \pm 0.43$ & & \multirow[t]{2}{*}{$-1.00 \pm 0.56$} & & \multirow{2}{*}{$0.35 \pm 0.50$} \\
\hline & $\Psi(.) \mathrm{p}()$. & 2 & 2.13 & & $0.09 \pm 0.37$ & & & & \\
\hline \multirow[t]{6}{*}{ Helobdella triserialis lineata } & $\Psi(\mathrm{DO}+\mathrm{DIN}) \mathrm{p}()$. & 4 & 0.00 & \multirow{6}{*}{0.56} & $-9.68 \pm 5.47$ & $-4.26 \pm 2.40$ & \multirow{6}{*}{$\begin{array}{l}-2.15 \pm 1.13 \\
-2.00 \pm 1.17\end{array}$} & & \multirow[t]{6}{*}{$-8.15 \pm 5.15$} \\
\hline & $\Psi(\mathrm{DO}+\mathrm{BOD} 5) \mathrm{p}()$. & 4 & 4.20 & & $-3.12 \pm 1.00$ & $-2.40 \pm 1.09$ & & & \\
\hline & $\Psi(\mathrm{DO}+\mathrm{BOD} 5+$ Conductivity) $\mathrm{p}()$. & 5 & 5.98 & & $-3.21 \pm 1.07$ & $-2.57 \pm 1.22$ & & $-0.38 \pm 0.79$ & \\
\hline & $\Psi($ DO + Conductivity $) \mathrm{p}()$. & 4 & 8.89 & & $-2.49 \pm 0.77$ & $-1.56 \pm 0.86$ & & $-0.83 \pm 0.59$ & \\
\hline & $\Psi(\mathrm{DO}) \mathrm{p}()$. & 3 & 8.98 & & $-2.15 \pm 0.59$ & $-0.83 \pm 0.52$ & & & \\
\hline & $\Psi(.) \mathrm{p}()$. & 2 & 9.84 & & $-1.91 \pm 0.50$ & & & & \\
\hline
\end{tabular}
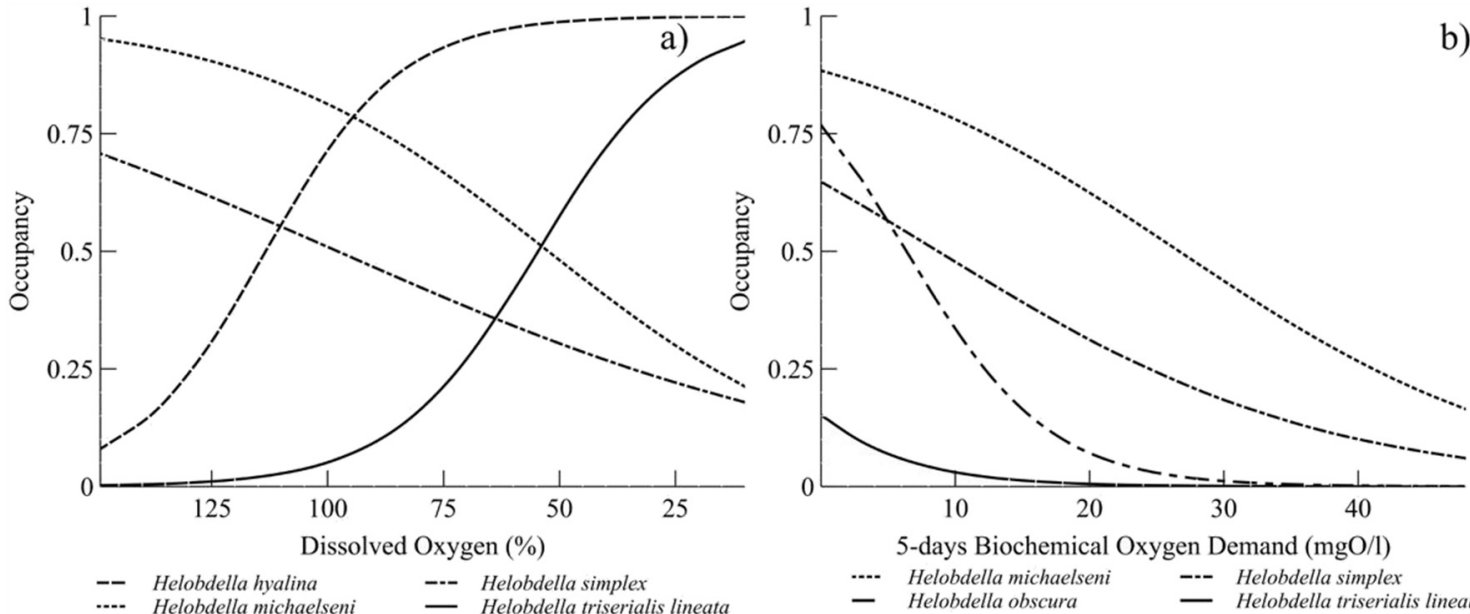

5-days Biochemical Oxygen Demand (mgO/l) $\begin{array}{lll}-\cdot- & \text { Helobdella michaelseni } & \text {--- Helobdella simplex } \\ \text { - Helobdella obscura } & - & \text { Helobdella triserialis lineata }\end{array}$
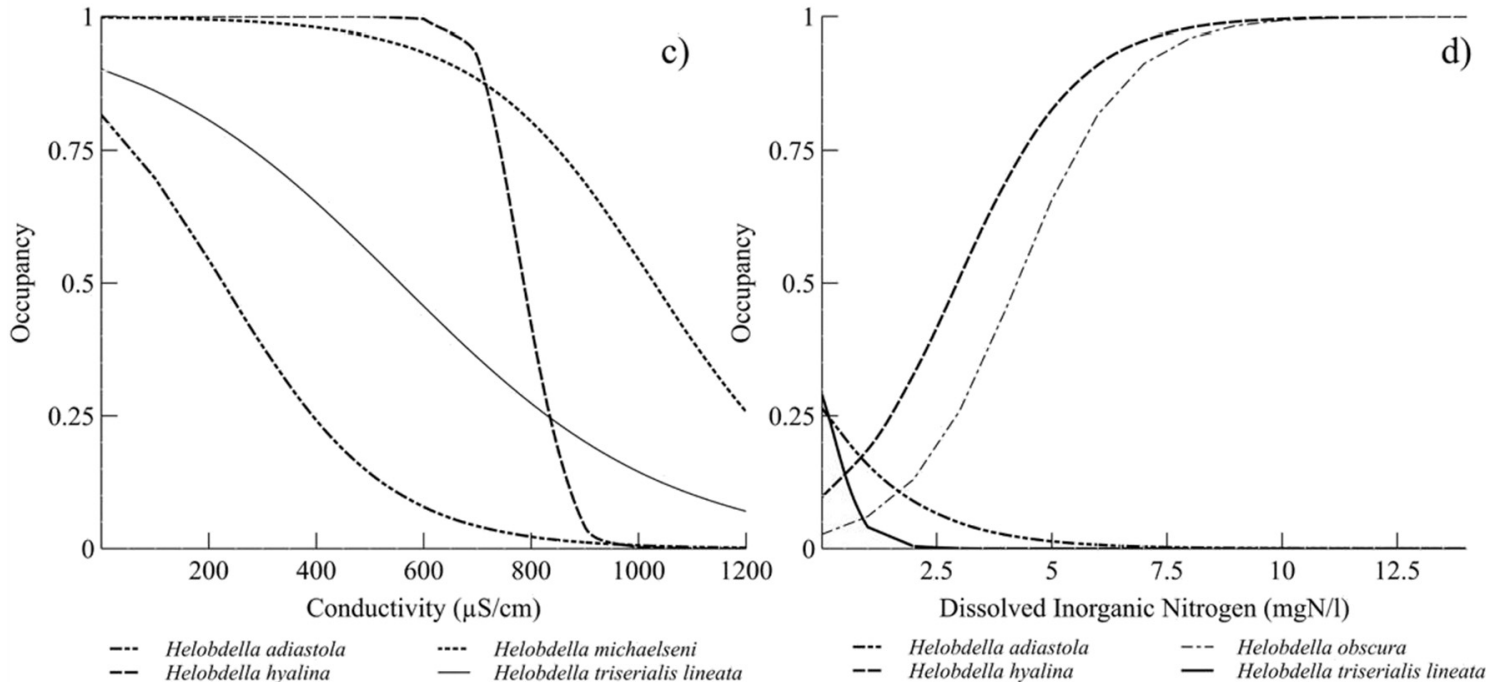

-- Helobdella adiastola

-.- Helobdella michaelseni

--- Helobdella adiastola

-.- Helobdella obscura

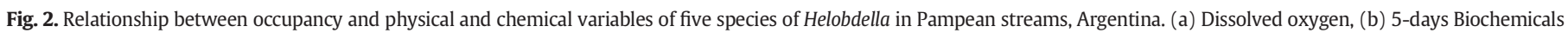
Oxygen Demand, (c) Conductivity, and (d) Dissolved Inorganic Nitrogen. 
The richness of leeches decreases in relation to organic pollution (Gullo and Darrigran, 1991). However, some species, as H. simplex, seem tolerant to the organic enrichment (Miserendino and Gullo, 2014). Our result agreed with previous observations, $H$. michaelseni and $H$. simplex showed a very long tolerance phase for $\mathrm{BOD}_{5}$ occurring even in high concentrations of this variable. At least in the surveyed streams of the region, the occupancy of the latter species would be a good indicator of organic pollution.

As occurs in many other invertebrate taxa, leeches showed a negative relationship between occupancy and conductivity (Cortelezzi et al., 2017). However, the response to conductivity was different for each one of the four modelled species. Helobdella hyalina showed a high resistance phase, and this observation is like the pattern previously observed in this species (César et al., 2009). A similar pattern was observed in $H$. michaelseni, with an even longer tolerance phase, being the most tolerant modelled species (i.e. it could be found in values up to $1200 \mu \mathrm{S} / \mathrm{cm}$ ). One single species, $H$. hyalina showed a positive relationship with dissolved inorganic nitrogen (DIN). This contra-intuitive behaviour was described for other leech species; where their occurrences were partially explained by a positive correlation with the concentration of nitrates (Jablonska-Barna et al., 2017).

In some of modelled species, occupancy was not explained by physical or chemical covariates. In those cases, occupancy could be affected by other ecosystem attributes such as the presence of resources, competitors, predators, and/or type of sediment. Food availability would be an important factor to explain the occupancy of leech's species (Sawyer, 1986). The species of Helobdella feed on a large diversity of invertebrates, which occurrence could be conditioned by physical and chemical variables (Sawyer, 1986). Moreover, there is a high correlation between type of sediment and the presence of $H$. obscura and $H$. michaelseni (Gullo and Darrigran, 1991; Gullo, 2015; Pamplin et al., 2006). Other species showed similar patterns. For example, $H$. simplex is common in a wide variety of habitats (i.e., sand, stone and trunks; Gullo and Darrigran, 1991); while H. adiastola is more often registered in soft sediment (e.g., silt, Gullo, 2015).

Until now limnologists usually report sensitivity, at genus or family levels, based on empirical derivation of presence of taxa in relation to ecosystem attributes (Alba-Tercedor et al., 2017; O'Callaghan and Kelly-Quinn, 2017). Our occupancy modelling approach allowed us to describe the differential contribution of each species to the sensitivity of the genus or family level to ecosystem attributes. For example, if we analyse the sensitivity of the genus Helobdella to dissolved oxygen, we can say that it is very tolerant and we could find it in sites with a wide range of values. However, if we analyse the response to dissolved oxygen of each one of the species of Helobdella, we will realize that H. michaelseni, and H. simplex showed a high occupancy at high levels of dissolved oxygen; while $H$. hyalina and $H$. triserialis lineata showed high occupancy at low levels.

Describe the sensitivity of the species in terms of occupancy, offers a new methodology to understand how the species behave along a stressor gradient. Further studies about sensitive of local species to different types of stressors will allow researchers to generate more accurate biotic indices.

\section{Acknowledgements}

We thank Jorge Donadelli (Laboratory of Chemistry, ILPLA) for the nutrient and oxygen demand analyses of water samples; IFIMAT for built our Ekman grab; and Claudio Santiago and Scout de la Ciencia (Scouts de Argentina) for the assistance in the field. Funding was provided by Consejo Nacional de Investigaciones Científicas y Tecnológicas (CONICET PIP 2015010598), Agencia Nacional de Promoción Científica y Tecnológica (PICT 2013-2039, PICT 2015-2281).

\section{References}

Alba-Tercedor, J., Sáinz-Bariáin, M., Poquet, J.M., Rodríguez-López, R., 2017. Predicting river macroinvertebrate communities distributional shifts under future global change scenarios in the Spanish Mediterranean area. PLoS One 12 (1), e0167904. https:// doi.org/10.1371/journal.pone.0167904.

American Public Health Association - APHA, 1998. Standard Methods for Examination of Water and Wastewater. 20th ed. APHA, American Water Works Association and Water Pollution Control Federation, Washington.

Bailey, L.L., MacKenzie, D.I., Nichols, J.D., 2014. Advances and applications of occupancy models. Methods Ecol. Evol. 5, 1269-1279.

Berkunsky, I., Simoy, M.V., Cepeda, R.E., Marinelli, C., Kacoliris, F., Daniele, P.G., Cortelezzi, A., Díaz-Luque, J., Friedman, M., Aramburú, R.M., 2015. Assessing the use of 209 forest islands by parrot species in a neotropical savanna. Avian Conserv. Ecol. 10 (210), 11.

Bilenca, D., Miñarro, F., 2004. Identificación de Áreas Valiosas de Pastizal (AVP) en las Pampas y Campos de Argentina, Uruguay y sur de Brasil. Fundación Vida Silvestre Argentina, Buenos Aires.

Boyce, M.S., Johnson, C.J., Merrill, E.H., Nielsen, S.E., Solberg, E.J., van Moorter, B., 2016. Can habitat selection predict abundance? J. Anim. Ecol. 85, 11-20.

Burnham, K.P., Anderson, D.R., 2002. Model Selection and Multimodel Inference: A Practical Information-Theoretic Approach. Springer-Verlag.

César, I.I., Martín, S.M., Gullo, B.S., Liberto, R., 2009. Biodiversity and ecology of Hirudinea (Annelida) from the Natural Reserve of Isla Martín García, Río de la Plata, Argentina. Braz. J. Biol. 69, 1107-1113.

Christoffersen, M., 2009. A catalogue of Helobdella (Annelida, Clitellata, Hirudinea Glossiphoniidae), with a summary of leech diversity from South America. Neotropical Biol. Conserv. 4, 89-98.

Chyla, M.A., 1998. An attempt to application of benthic macroinvertebrates for the assessment of water quality. Acta Hydrobiol. 40, 55-65.

Cortelezzi, A., Armendáriz, L., Simoy, M.V., Marinelli, C.B., Cepeda, R.E., Rodrigues Capítulo A., Berkunsky, I., 2017. Site-occupancy modelling: a new approach to assess sensitivity of indicator species. Ecol. Indic. 79, 191-195.

Fiske, I., Chandler, R.B., 2011. Unmarked: an R package for fitting hierarchical models of wildlife occurrence and abundance. J. Stat. Softw. 43, 1-23.

Gullo, B.S., 2006. Helobdella nahuelhuapensis sp. nov. (Hirudinea, Glossiphoniidae), from Bariloche, Argentina. Zootaxa (Nueva Zelanda ISSN 1175-5334, on line Edition). 1276 pp. 33-38.

Gullo, B.S., 2009. A new leech species of Helobdella (Hirudinea, Glossiphoniidae) from San Carlos de Bariloche, Río Negro, Argentina. Revista Mexicana de Biodiversidad 80, 47-50.

Gullo, B.S., 2014. Biodiversidad de Hirudinea en ambientes dulceacuícolas serranos (Provincia de Buenos Aires), Argentina. Revista del Museo de la Plata Sección Zoología 23, 1-11.

Gullo, B.S., 2015. Nuevos registros de especies de la familia Glossiphoniidae (Annelida, Clitellata, Hirudinida) en la Comarca de Sierra de la Ventana (Provincia de Buenos Aires, Argentina). Natura Neotropicalis 46, 25-40.

Gullo, B.S., Darrigran, G., 1991. Distribución de la fauna de hirudíneos litorales del estuario del Río de la Plata, República Argentina. Biología Acuática 15, 216-217.

Jablonska-Barna, I., Bielecki, A., Cichocka, J.M., Buczynska, E., Bucynski, P., Walerzal, A 2017. Environmental factors determining the distribution pattern of leeches (Clitellata: Hirudinida) in large river systems: a case study of the Order River System. Biologia, Section Zool. 4, 407-416.

Kazancı, N., Ekingen, P., Dugel, M., Turkmen, G., 2014. Hirudinea (Annelida) species and their ecological preferences in some running waters and lakes. Int. J. Environ. Sci. Technol. 12, 1087-1096.

Kubová, N., Schenková, J., 2014. Tolerance, optimum ranges and ecological requirements of free-living leech species (Clitellata: Hirudinida). Fundam. Appl. Limnol. 185, $167-180$.

Lenat, D.R., 1993. A biotic index for the southeastern United States: derivation and list of tolerance values, with criteria for assigning water-quality ratings. J. N. Am. Benthol. Soc. 12, 279-290.

Leonardsson, K., Blomqvist, M., Rosenberg, R., 2009. Theoretical and practical aspects on benthic quality assessment according to the EU-Water Framework Directive - examples from Swedish waters. Mar. Pollut. Bull. 58, 1286-1296.

Mackereth, F.J.H., Heron, J., Talling, J.F., 1978. Water Analysis: Some Revised Methods for Limnologists. Vol. 36. Freshwater Biological Association, Scientific Publication (120 p).

Maxted, J.R., Barbour, M.T., Gerritsen, J., Poretti, V., Primrose, N., Silvia, A., Penrose, D., Renfrew, R., 2000. Assessment framework for mid-Atlantic coastal plain streams using benthic macroinvertebrates. J. N. Am. Benthol. Soc. 19, 128-144.

Miserendino, M.L., Gullo, B.S., 2014. Occurrence of Hirudinea species in a post urban reach of a Patagonian mountain stream. Iheringia, Série Zoologia. 104, pp. 308-313.

Mosser, W., Steven, V.F., Richardson, D., Hammond, C.I., Lazo-Wasem, E., Govedich, F.R., Gullo, B., 2013. A new species of Helobdella (Hirudinida: Glossiphoniidae) from Oregon, USA. Zootaxa 3718, 287-294.

O'Callaghan, P., Kelly-Quinn, M., 2017. Distribution and structure of lotic macroinvertebrates communities and the influence of environmental factors in a tropical cloud forest, Cusuco National Park, Honduras. J. Limnol. 76, 148-160.

Oceguera-Figueroa, A., 2014. Biodiversidad de sanguijuelas (Annelida: Euhirudinea) en México. Revista Mexicana de Biodiversidad Supl. 85, 183-189.

Oceguera-Figueroa, A., León-Regagnon, V., Siddall, M., 2010. DNA barcoding reveals Mexican diversity within the freshwater leech genus Helobdella (Annelida: Glossiphoniidae). Mitochondrial DNA 21, 24-29.

Pamplin, P.A.Z., Almeida, T.C.M., Rocha, O., 2006. Composition and distribution of benthic macroinvertebrates in Americana Reservoir (SP, Brazil). Acta Limnol. Bras. 18, $121-132$. 
Pearson, T.H., Rosenberg, R., 1978. Macrobenthic succession in relation to organic enrichment and pollution of the marine environment. Oceanogr. Mar. Biol. 16, 229-311.

Pizzolón, L., Miserendino, M.L., 2001. The performance of two regional biotic indices for running water quality in Northern Patagonian Andes. Acta Limnol. Bras. 13, 11-27.

Ringuelet, R., 1985. Annulata. Hirudinea. In: Castellanos, Z.A. (Ed.), Fauna de agua dulce de la República Argentina. 27, pp. 1-321.

Rosenberg, D.M., Resh, V.H., 1993. Freshwater Biomonitoring and Benthic Macroinvertebrates. Chapman and Hall, New York

Rosenberg, R., Blomqvist, M., Nilsson, C.H., Cederwall, H., Dimming, A., 2004. Marine quality assessment by use of benthic species-abundance distributions; a proposed new protocol within the European Union Water Framework Directive. Mar. Pollut. Bull. 49, 728-739.

Royer, T.V., Robinson, C.T., Minshall, G.W., 2001. Development of macroinvertebratebased index for bioassessment of Idaho rivers. Environ. Manag. 27, 627-636.
Sawyer, R.T., 1986. Leech biology and behaviour. Feeding, Biology, Ecology and Systematic. Oxford University Press, Oxford.

Siddall, M., 2001. Leeches of Laguna Volcán, Bolivia, including a new Species of Helobdella (Clitellata: Hirudinea). Am. Mus. Novit. 3313, 1-11.

Siddall, M., Borda, E., 2004. Leech collections from Chile including two new species of Helobdella (Annelida: Hirudinida). Am. Mus. Novit. 3457, 1-18.

Siddall, M., Budinoff, R.L., Borda, E., 2005. Phylogenetic evaluation of systematic and biogeography of the leech family Glossiphoniidae. Invertebr. Syst. 19, 105-112.

Sket, B., Trontelj, P., 2008. Global diversity of leech. Hydrobiologia 525, 129-137.

Skriver, J., Friber, N., Kirkegaard, J., 2000. Biological assessment of running water in Denmark: introduction of the Danish Stream Fauna Index (DSFI). Verhandlungen des Internationalen Verein Limnologie 27, 1822-1830. 